\title{
Flying Squirrel Nests in Fire Tower
}

by S. A. Mernitz, Fish and Game League of Regina

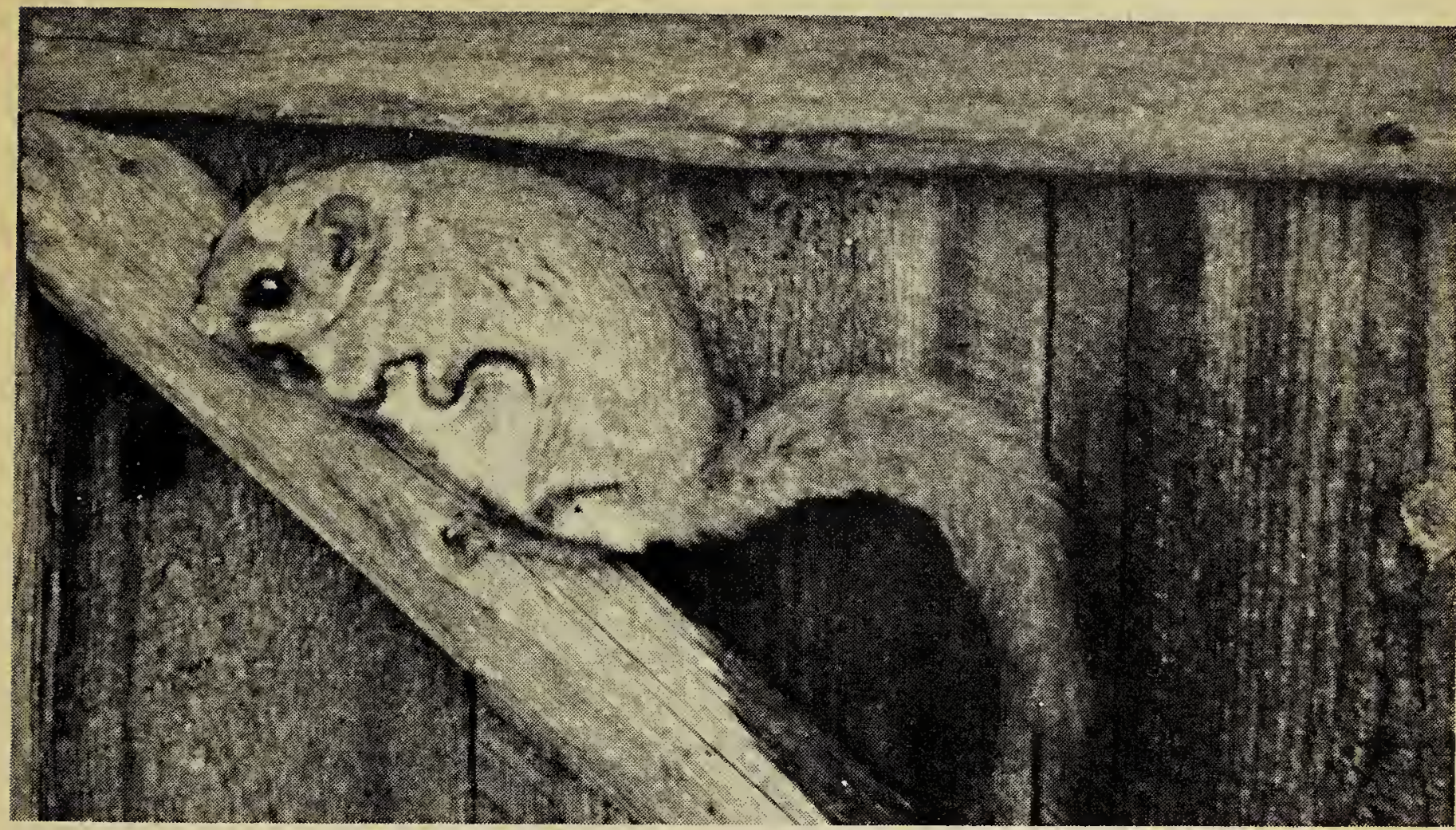

On July 14, 1960, I stopped in at Midnight Tower, manned by Jack Davies. Being a camera fan I asked him, half joking, if he had any wildlife for a photographer. His reply was that on top of the tower a family of Flying Squirrels had been nesting and as the young ones were about

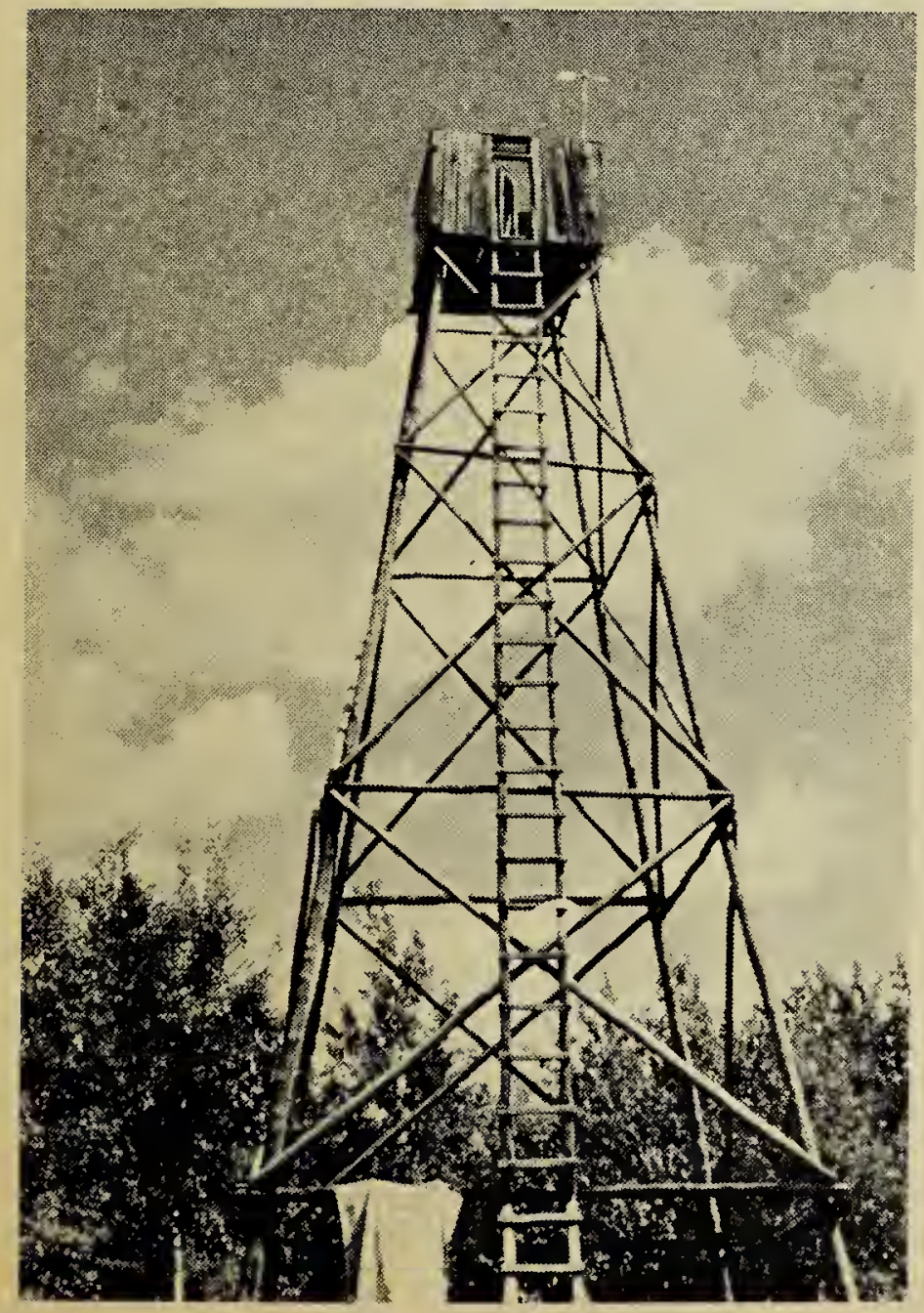

half-grown one or two might still be there. I ascended the wooden 35footer, which is a secondary fire control tower approximately. 50 miles south of Meadow Lake in the Glaslyn district. I found a wooden box used as a seat by the lookout filled with leaves and grass and the two young squirrels. As I tried to lure them out into the open one darted up to the railing of the platform and jumped. I watched it gracefully glide down. The second squirrel, still within the box, was not quite so willing to leave. However, after a little persuasion, it, too, came out and it dashed to the spot where I took the above picture. I was none too soon for the whirring of the shutter must have scared the little fellow. It, too, jumped and sailed down to the trees below.

\section{BOBCAT COLLECTED NEAR REGINA}

by Albert Swanston, Saskatchewan Museum of Natural History

On December 3, 1960, while checking traps in the Bredin vicinity, about 12 miles northwest of Regina, I was very surprised to find that I had trapped a young Bobcat (Lynx rufus). Having trapped in this general area for a number of years I was aware that Bobcats were generally 
uncommon here. Recently, while talking to Rolland Fenwick of Regina about this record he told me that he had seen two Bobcats this year while bow-hunting for deer in the Qu'Appelle River valley (near the Regina Natural History Society's "Hidden Valley") about 20 miles northwest of Regina. This area is more of a wilderness than is generally suspected, many deep ravines and extensive woods being found especially along the north-facing slopes of the Qu'Appelle valley and in the tributary valleys. Boggy Creek at Bredin, for example, where I took the Bobcat and where Frank Brazier reported a Mountain Lion (Blue Jay, 18: 182-183), is rather extensively wooded and deer and other forms of wildlife are numerous throughout these areas. The Bobcat specimen, a half-grown female (weight 6 lbs. 15 oz.) is now in the study collections of the Saskatchewan Museum of Natural History. It is the first known record for the Regina vicinity.

$E d$. Note: The range of the Bobcat in Saskatchewan is believed to be limited to the extreme south and southwest, generally south of the Qu'Appelle River on the east, and the South Saskatchewan River (from Elbow) on the west. (Hall and Kelson, 1959. Mammals of North America, Vol. II. Ronald Press, N.Y.; Beck, 1958. A guide to Saskatchewan mammals. Sask. Natural History Society). This distribution is supported by fur-return records for 1957 (which are basad on game manage- ment zones, thus limiting their usefulness) supplied through the courtesy of $T$. Harper, Assistant Director, Wildlife Branch, Dept. of Natural Resounces. The Bobcat should be considered a rare animal. Further records are needed to establish its actual range and status. -R.W.N.

\section{Summer Record of a Silver-haired Bat in Southern Saskatchewan}

by R. W. Nero, Saskatchewan Museum of Natural History

The occasional occurrence of the Silver-haired Bat (Lasionycteris noctivagans) on the plains of southern Saskatchewan in summer, presumably as a rare breeding species, even as far south as Govenlock, has previously been noted (Blue Jay, 15: $38-41,46,121)$. A most recent record has been obtained for the extreme south-central region. A female Silver-haired Bat was submitted to the Museum for verification and for the record by Ronald Mayer, who reports that he found it at Bengough, Saskatchewan, on June 30,1960 , on the roof of a garage where it had been trapped by one wing caught beneath a loose shingle. Ronald states that this was the first bat which he had seen around the farm for many years.

\section{The Mud Dauber Wasp}

by Marion Nixon, Wauchope

The subject of the article appeared "in person" to remind me! Sluggishly wandering along a chair back, after a heavy flight from the chilly win-

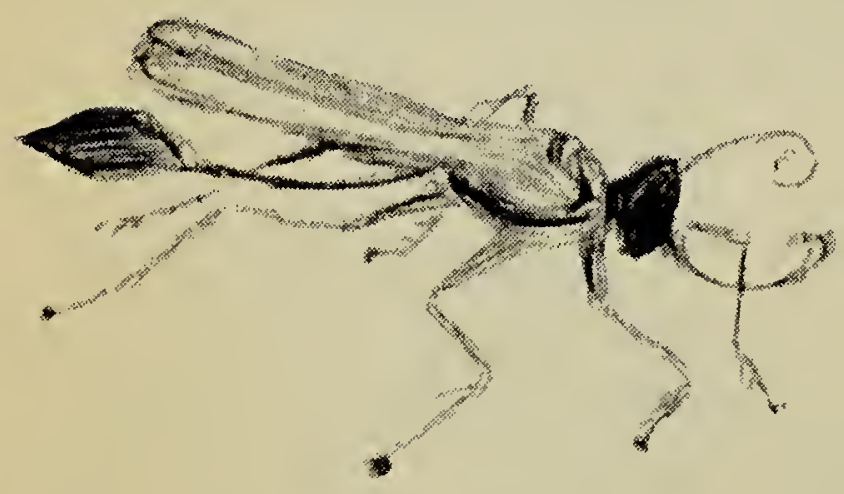
dowpane, my unexpected visitor was easily captured under a glass tumbler and is now sitting on a saucer at my side.

It is a long, slim, svelte queen thread-waisted wasp, which has left the sanctuary of our attic, where Mud Dauber nests of various sizes : stud the rafters. From the "new look" she wears, her black and gold still unsullied by hard wear, she probably stirred to life in a mistaken belief that furnace heat meant spring.

This afternoon of December 29, I am reminded of the article I promised, last summer, to prepare for the Blue Jay.

We have watched her supping on moisture from sides of the glass 